\title{
INFLUENCE OF APPLIED ELECTRON RADIATION ON THE PROPERTIES OF A POLYAMIDE 11 SURFACE LAYER
}

\author{
VPLIV OBSEVANJA Z ELEKTRONI NA LASTNOSTI POVRŠINSKE \\ PLASTI POLIAMIDA 11
}

\author{
Martin Ovsik*, Petr Fluxa, Michal Stanek, Adam Dockal, Martin Reznicek \\ Tomas Bata University in Zlín, Vavrečkova 275, 76001 Zlín, Czech Republic \\ Prejem rokopisa - received: 2019-07-15; sprejem za objavo - accepted for publication: 2019-12-23
}

doi: $10.17222 /$ mit.2019.155

\begin{abstract}
This article deals with the influence of the radiation cross-linking of polyamide 11 (PA 11) on the mechanical properties. The aim of this study is to provide more detailed knowledge of the relation between the radiation dosage and the properties of cross-linked PA 11 and its mechanical behaviour. Electron-beam-unmodified and modified PA 11 test samples were exposed to electron radiation with dosages from $0 \mathrm{kGy}$ to $198 \mathrm{kGy}$, which were graded at $33 \mathrm{kGy}$. The surface-layer properties of the modified PA 11 were tested using a state-of-the-art indentation technique, which detects the immediate change in the indentation depth, depending on the applied force. The evaluation of the measured mechanical properties (indentation hardness, modulus and creep) was done by the Oliver and Pharr method. A significant influence of the radiation cross-linking on the PA 11's mechanical properties improvement was confirmed by the measurements. This enhancement grows with the increasing radiation dosage. Due to the electron-radiation modification of PA 11, the mechanical properties of the surface layer were increased by up to $59 \%$ compared with the unaltered material. Radiation crosslinking is an important thermoplastic modification method by which the desired properties can be achieved in a relatively short period of time. The main advantage is that the process is executed on the final product.

Keywords: polyamide, radiation, mechanical properties, indentation hardness
\end{abstract}

V članku avtorji opisujejo vpliv obsevanja prečno zamreženega poliamida 11 (PA11) na mehanske lastnosti. Študija naj bi zagotovila bolj natančen vpogled v poznavanje povezav med dozo obsevanja in lastnostmi prečno zamreženega PA 11 ter njihovim vplivom na mehanske lastnosti. Analizirali so originalne neobsevane vzorce in vzorce PA 11, obsevane s snopom elektronov z dozami med 0 in $198 \mathrm{kGy}$ v stopnjah po $33 \mathrm{kGy}$. Lastnosti površinske plasti obsevanih vzorcev PA 11 so testirali z najmodernejšo indentacijsko tehniko, ki takoj zazna spremembe indentacijske (vdorne) globine v odvisnosti od uporabljene sile vtiskovanja trna (indenterja) v preiskovani material. Avtorji članka so ovrednotili rezultate izmerjenih mehanskih lastnosti (nanotrdoto, modul in lezenje) z Oliver in Phaar metodo. Rezultati meritev so pokazali pomemben vpliv obsevanja prečno zamreženega PA 11 na mehanske lastnosti. S povečano stopnjo obsevanja so se izboljševale mehanske lastnosti. Zaradi obsevanja P11 z elektroni so se mehanske lastnosti površinske plasti izboljšale za do $59 \%$ v primerjavi z vzorci, ki niso bili obsevani. Prečno zamreženje zaradi obsevanja z elektroni je pomembna metoda termoplastične modifikacije, ki lahko hitro izboljša oz. modificira lastnosti površine izbranega materiala. Pomembna prednost je v tem, da lahko proces izvedemo na končnih izdelkih.

Ključne besede: poliamid, obsevanje, mehanske lastnosti, nanotrdota

\section{INTRODUCTION}

In general, polyamides have medium durability to ionizing radiation. This durability, for the polyamide types - $\mathrm{CONH}-\left(\mathrm{CH}_{2}\right) \mathrm{n}-$, decreases with the increasing number of the methyl groups in between the peptide links. As a result of sample irradiation, a process of cross-linking as well as fission commences. For most of the polyamides, the cross-linking process is prevalent, although, the process of network construction is not very strong. According to K. Kaindl and E. H. Graul, ${ }^{1}$ free radicals begin to form within the structure during irradiation. Simultaneously, radicals are created around the $\mathrm{C}=\mathrm{N}$ and $\mathrm{C}=\mathrm{C}$ double bonds. According to $\mathrm{K}$. Kaindl and E. H. Graul ${ }^{1}$ a radiation dosage of $350 \mathrm{kGy}$ with oxygen present incites the creation of gel. When the irradiation occurs in a vacuum, the cross-linking process

*Corresponding author's e-mail:

ovsik@utb.cz (Martin Ovsik) is prevalent, which leads to changes that improve the mechanical properties.

Adding a poly-functional monomer, e.g., triallyl isocyanurate (TAIC), enables the polyamides to begin the cross-linking process after being exposed to relatively low dosages of radiation, when the oxygen is present. Finding out the correct dosages for the improvement of the selected mechanical properties is the goal of this research paper. First, hydrogen bound to the carbon neighbouring with the nitrogen of the amide group is split, leading to the creation of water, carbon monoxide, carbon dioxide and methane. Three allyl groups of TAIC can, due to the irradiation, react and create additional bridges (network) in the polyamide structure. ${ }^{2}$

\section{EXPERIMENTAL PART}

For this experiment, PA11 called V-PTS-CREAMID$11 \mathrm{~T} * \mathrm{M} 600 / 13$ manufactured by PTS was used. To 


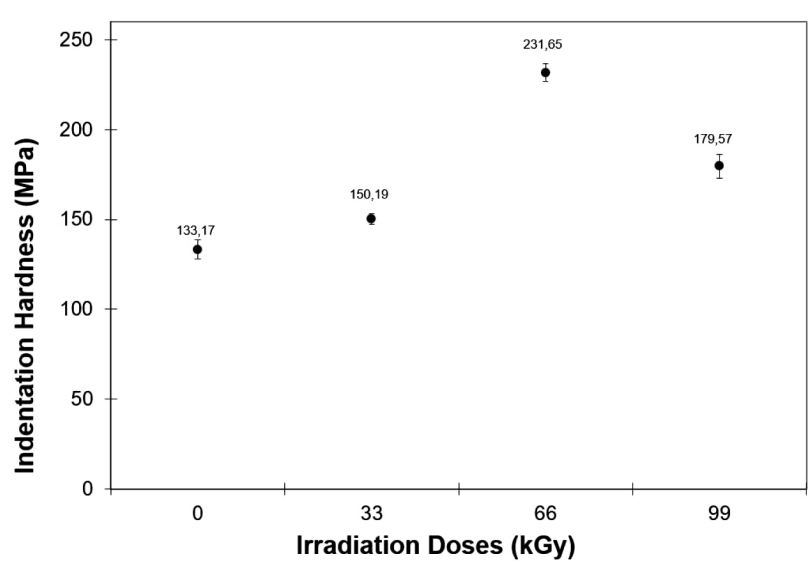

Figure 1: Indentation hardness

ensure the radiation induced cross-linking a cross-linking agent triallyl isocyanurate (TAIC) in $5 \%$ volume was added. The samples were prepared by injection moulding on an Allrounder 470E-type ARBURG injectionmoulding machine. The parameters of the machine were set according to the recommendation of the manufacturer. The material that was used was pre-dried in accordance with the instructions on an ARBURG THERMOLIFT 100-2 device. The test samples were prepared in a single-cavity mould in the shape of the beam, in agreement with the ČSN EN ISO 179 standard.

The test samples were exposed to the radiation in cooperation with company BGS Beta-Gamma-Service $\mathrm{GmbH} \& \mathrm{Co}$. KG in a high-voltage accelerator-type Rhodotron. The radiation dosages were set to $33 \mathrm{kGy}$, $66 \mathrm{kGy}$ and $99 \mathrm{kGy}$.

The mechanical properties of the surface layer were measured by the depth sensing indentation (DSI) on an ultra nano-indentation system (UNHT). ${ }^{3}$ The parameters were set to the following values: applied load $50 \mathrm{mN}$, loading and de-loading speed $100 \mathrm{mN} / \mathrm{min}$ and load duration $90 \mathrm{~s}$. The measurements were made according to the ČSN EN ISO 14577 standard and then evaluated using the Oliver and Pharr method. ${ }^{3}$

\section{RESULTS}

The indentation hardness and modulus of the PA11 modified by various dosages of radiation were measured by the DSI. Each sample was measured 10 times and the results were afterwards statistically evaluated.

\section{DISCUSSION}

As can be seen in Figure 1, the indentation hardness was gradually increased due to the radiation cross-linking, even at the lower dosages. The highest values were measured in the material irradiated by a dose of $66 \mathrm{kGy}$, in which the indentation hardness rose by $73 \%$ in comparison to the unaltered material. It is noteworthy that even the relatively low amounts of radiation ( $33 \mathrm{kGy})$

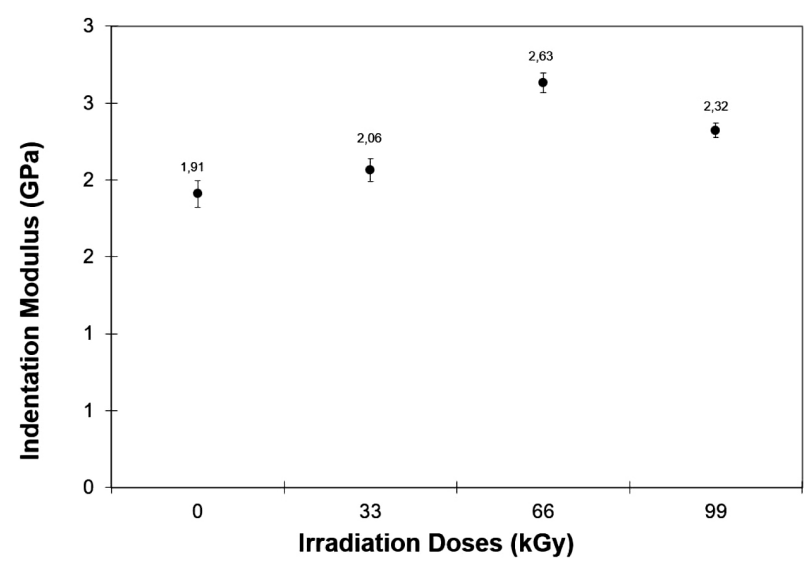

Figure 2: Indentation modulus

increased the indentation modulus by $13 \%$. Additional levels of radiation displayed only a minor increase in the indentation hardness and modulus. In contrast, the use of radiation dosages of 99 and higher kGy caused the indentation modulus to decline. Considering the cost of the irradiation, it is non-profitable to consider higher dosages than $66 \mathrm{kGy}$ for the indentation modulus.

As is evident from the measurements of the PA11 indentation elastic modulus at room temperature, the modulus rose with the increasing radiation dosage (Figure 2). The highest values of the indentation modulus were measured in the test samples irradiated by a dosage of $66 \mathrm{kGy}$. This modulus was $37 \%$ higher in comparison to the virgin material. Indeed, it can be said that the radiation cross-linking had a positive influence on the indentation modulus of the PA11. Radiation dosages higher than $66 \mathrm{kGy}$ displayed a decreasing trend in the mechanical properties of the surface layer, which could have been caused the material degradation induced by the large amounts of radiation.

\section{CONCLUSIONS}

The measured data indicate that the most suitable dosage of radiation for the chosen materials appears to be $66 \mathrm{kGy}$. This value induced positive changes in the mechanical properties for each observed test sample. The improvements to the indentation hardness and indentation modulus directly caused by the radiation crosslinking are a desired result for some of the technical applications. The best enhancements of the indentation hardness were found in the test samples that were irradiated with dosages of $33 \mathrm{kGy}$ or $66 \mathrm{kGy}$. Radiation dosages higher than these proved to significantly decrease the indentation modulus and indentation hardness in the observed test samples. This decline could be caused by the material degradation induced by the high dosages of electron radiation. 
M. OVSIK et al.: INFLUENCE OF APPLIED ELECTRON RADIATION ON THE PROPERTIES ...

\section{Acknowledgment}

This work was supported by the European Regional Development Fund under the project CEBIA-Tech Instrumentation No. CZ.1.05/2.1.00/19.0376 and by the Ministry of Education, Youth and Sports of the Czech Republic within the National Sustainability Program project no. LO1303 (MSMT-7778/2014). Moreover, it was supported by the Internal Grant Agency of TBU in Zlin: no. IGA/2020/003.

\section{REFERENCES}

${ }^{1}$ K. Kaindl, E. H. Graul, Strahlenchemie, Dr. Alfred Hüttig Verlag, Heidelberg, 1967

${ }^{2}$ M. Ghidelli, M. Sebastiani, K. E. Johanns, Journal of the American ceramic society, 100 (2017), 5731-5738

${ }^{3}$ W. C. Oliver, G. M. Pharr, Measurement of hardness and elastic modulus by instrumented indentation, Journal of Materials Research, 19 (2004), 1564-1583 